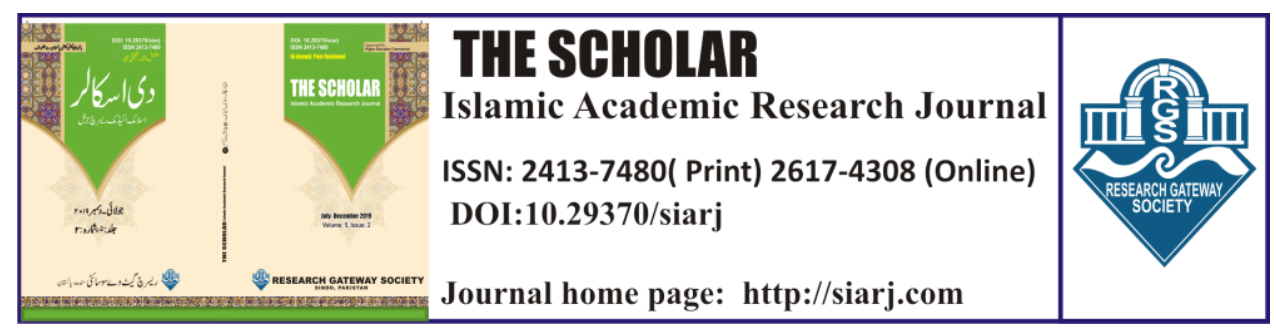

\title{
CURRICULUM OF ISLAMIC INSTITUTES IN SUB CONTINENT (A CRITICAL ANALYSIS)
}

\section{Abdul Hai Madni}

Associate Professor, NED University of Engineering and Technology Karachi Pakistan

Email: dr.madni67@gmail.com

ORCID ID:

https://orcid.org/0000-0002-6074-2845

\section{Naseem Akhtar}

Assistant Professor, , Shaheed

Benazir Bhutto Women University

Peshawar, Pakistan

Email:khtrnnsm@yahooo.com

ORCIID IID:

https://orcid.org/0000-0002-7077-6993

\section{Muhammad Asif Nadeem}

Assistant professor, Department of Education, the Islamia University of

Bahawalpur. Pakistan.

Email: Chughtaima@gmail.com

ORCIID IID:

https://orcid.org/0000-0002-0494-8443

To cite this article:

Madni, Abdul Hai, Naseem Akhter, and Muhammad Asif Nadeem.

"CURRICULUM OF ISLAMIC INSTITUTES IN SUB CONTINENT (A

CRITICAL ANALYSIS)." The Scholar-Islamic Academic Research Journal 6, no. 1 (May 31, 2020): 135-62.

To link to this article: https://doi.org/10.29370/siarj/issue10ar12

\begin{tabular}{|c|c|}
\hline Journal & $\begin{array}{l}\text { The Scholar Islamic Academic Research Journal } \\
\text { Vol. 6, No. } 1 \text { || January -June } 2020 \text { || P. 135-162 } \\
\text { Research Gateway Society }\end{array}$ \\
\hline Publisher & Research Gateway Society \\
\hline DOI: & $\underline{10.29370 / \text { siari/issue10ar12 }}$ \\
\hline URL: & https://doi.org/10.29370/siari/issue10ar12 \\
\hline License: & Copyright c 2017 NC-SA 4.0 \\
\hline Journal homepage & www.siari.com \\
\hline Published online: & $2020-05-31$ \\
\hline
\end{tabular}
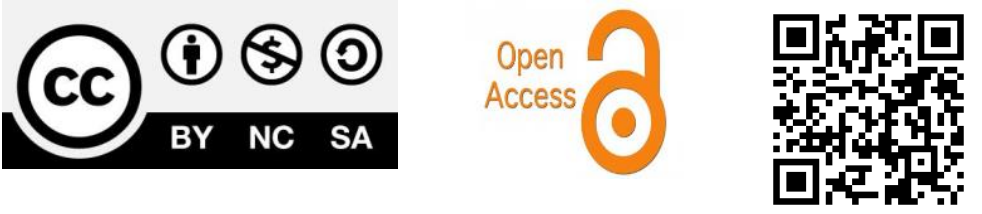
THE SCHOLAR (January- June 2020)

\title{
CURRICULUM OF ISLAMIC INSTITUTES IN SUB CONTINENT \\ (A CRITICAL ANALYSIS)
}

Abdul Hai Madni, Naseem Akhtar, Muhammad Asif Nadeem

\begin{abstract}
:
The first goal of education in Islam is to nurture the abilities of man completely so that he becomes a good citizen. So that he lives his life according not only as part of society but according to modern times and trends. All this so that society gets betterment through him.To achieves this goal the Development of curriculum of educational institutes has a central role. This is because after the teacher and student the curriculum is the most important pillar of education. Adding to that no step in education is complete without it. Curriculum creation is systematic process where changing needs of society and the individual can be focused upon. Thus curriculum creation is an integral part of an educational system where the curriculum is designed by looking at the curriculum goals.
\end{abstract}

KEYWORDS: Historical Background, objectives, selection of the books, popularity, improvement and amendments, Modernization

INTRODUCTION:

In Pakistan the education is from both the religious and secular institutions thus the difference in their curriculum is like the 
distance between the east and the west. This separation was born during the British rule. ${ }^{1}$

There was no such separation before the British. After this separation the Islamic institutes looking at their cultural heritage chose a curriculum whose main aim was the continuation of Islamic education. That is why all the subject matter chosen which are included has a religious view while on the contrary the secular institutes made Islamic education a very small part of their curriculum. It should be kept in mind that curriculum creation had started since the time of Umayyads in Syria and surrounding areas the teaching of Ahaadith was done through structured classes where specific Ahaadith were taught and this was all supervised by eminent companions of the Prophet. $^{2}$

But In Pakistan the current curriculum in Islamic institutes is from the ideology of Mullah Nizam-ud-Din Sahalwi (1748 AD died) model called "Dars-e-Nizami".

${ }^{1}$ Bukhari, syed shabbier, mecallay aur barr-e-saghir ka nizam taleem, aaina adab, anar kali, Lahore, 1986, p:30

${ }^{2}$ Shuja-ud-din, weekly HIMAYAT, 25 October 1957 Bukhari, syed abdul ghaffar, ehad banu Umayyad may muhaddeseen ki khidmaat, nashriyaat, Lahore, p:138 
Although there have been changes made to it through time but still the foundation and subject distribution is based on "Darse-Nizami". The effect of "Dars-e-Nizami" is felt through all Islamic institutes from different schools of thought with amendments done through time.

\section{HISTORY OF "DARS-E-NIZAMI":}

The foundation of an Islamic government in Indian Subcontinent was set by Mahmood Ghaznavi in 11th century CE. ${ }^{3}(3)$

This resulted in the curriculum having the inclusion of quranic commentary, (Tafsir) prophetic Traditions (Hadith), Islamic law (Fiqh), science of Islamic law (Usool-Fiqh), Tasawwuf, Kalam, Arabic literature, Arabic Grammar (Nahw, Mantaq) etc. as subjects in it.

Through this it is clear that the majority of subjects were Islamic. The change happened to this curriculum during the time of Sikander Lodhi (1550-1489 CE) when transmitted subjects were reduced for intellectual subjects when there were

${ }^{3}$ Nadawi, abu-ul-hasanaat, Hindustan ki qadeem taleemi darsgahien, amrtasr, 1922, p:94 
only two intellectual subjects were to begin with. These were Ilm-Kalam and Ilm-Mantaq ${ }^{4}$

After Sikander Lodhi there were clear changes during the rule of Mughals. In King Akbar the Great time (1605 CE died).

In the time the religious views of Jalal-ud-Din Akbar had a big role and Deen-e-Ilahi is its biggest example. Therefore during his time for the first time Islamic curriculum had secular subjects included which was a revolutionary change.

Thus the curriculum had Citizenship, Economics, Astronomy, Science, Mathematics and Medicine all part of it. ${ }^{5}$

Due to the modern outlook of curriculum design a student after graduating from Islamic institutes had the opportunity to major in any subject he liked based on his inclinations and interests. In this curriculum the student had the complete authority to choose any one subject that he wanted to study from all the

${ }^{4}$ Gilani, manazar ahsan, hinustan may muslmano ka nizam-etaleem o tarbiyyat, dehli, 1944, V:1, P:317

${ }^{5}$ Ibid, $V: 1, P: 360$ 
subjects available. An eminent Muslim thinker Dr Mahmood Ghazi ${ }^{6}$ talks about the curriculum by stating:

"This curriculum or system was the proof of coming together of both the religion and the world. This curriculum created scholars like Mujadid Alf Thani and Nawab Sadullah Khan who both were students of one teacher. Nawab Sadullah Khan is a politician during the time of Shah Jahan was the Prime Minister of all of India for 48 years. That India is present day India, Pakistan, Afghanistan, Bangladesh, Sri Lanka and Nepal. Thus that states-man who ran big empires and forerunners in Islamic leadership (scholars like Mujadid Alf Thani) came through the same curriculum. Also the engineer who made the Taj Mahal went through the same curriculum. And now the Taj Mahal is one of the Seven Wonders of the World. ${ }^{7}$

The Mughal Emperor Aurangzeb Alamgir who was against Jalal-ud-Din Akbar helped in the eighteenth century Mullah

${ }^{6}$ A late former Muslim scholar has deliver famous lectures on different Islamic science like Quran and his principles at different places in Pakistan etc

${ }^{7}$ Nadawi, abu-ul-hasanaat, Hindustan ki qadeem taleemi darsgahien, amrtasr, 1922, p:95 
Curriculum of Islamic institutes in sub continent

Nizam-ud-Din Sahalwi in Lacknow by creating an institute in the place of a "Farangi Mahal" 8

For this institute Mullah Nizam Ad-Din Sahalwi made a curriculum which became popular by his name as "Dars-eNizami”.

In Pakistan, the Islamic institutes have this as a foundation of their curriculum with some amendments.

The curriculum of Mullah Nizam-ud-Din is laid out below:

1) Tafsir:

- Tafsir Jalalain: Jalal-ud-Din Sayyoti (911AH/1505 CE) and Jalal-ud-Din Mahalli (844 AH/1459 CE)

- Bedhawi: Nasir ad-Din Bedhawi (485 AH/1286 CE)

2) Hadith:

- Mishkaat ul Masabeeh, Abu Abdullah Muhammad bin Abdullah (760 AH)

\section{3) Fiqh}

- Hidayah: Allamah Burhan Ad-Din Marginani

- Sharh Wiqaya (Thani): Ubaidullah bin Masood Sadr AsShariah (747 AH/1346 CE)

${ }^{8}$ Ghazi, Dr Mahmood Ahmad, Muslmano ka deeni wa asri nizam taleem, compiled by Dr syed aziz-ur-rehman, al-shariah academy, Gujranwala, 2009, p:209-210 


\section{4) Usool Fiqh}

- Tawdeeh wa Talweeh: Saad Ad-Din Taftazani (792 $\mathrm{AH} / 1389 \mathrm{CE})$

- Noor Al-Anwar: Shaikh Ahmed bin Abi Said Mulla Jiwan (1130 AH/1718 CE)

- Muslim At-Thaboot: Qadi Muhibullah Bihari (1119 $\mathrm{AH} / 1707 \mathrm{CE})$

5) Nahw

- Nahw Meer: Syed Shareef Jurjani (814 AH/1413 CE)

- Sharh Miyah Amil: Hussain bin Addullah Nuqani (926 $\mathrm{AH} / 1520 \mathrm{CE})$

- Hidayah Nahw: Abu Hayan Muhammad bin Yusuf bin Ali (745 AH/1344 CE)

- Kafiyah: Ibn Hajib (646 AH/1249 CE)

- Sharh Jami: Noor Ad-Din Abdurahman Jami (898 $\mathrm{AH} / 1492 \mathrm{CE})$

\section{6) Sarf}

- Mizan: Mullah Hamza Bidauni, Manshab: Mullah Hamid Ad-Din Kakori (1215 AH/ $1801 \mathrm{CE})$

- Sarf Meer: Syed Shareef Jurjani (816 AH/1413 CE)

- Panj Ganj: Siraj Ad-Din Audohi (758 AH)

- Zubdah: Zahireen Mahmood bin Masood Alwi

- Fusool Akbari: Qadi Ali Akbar Hussaini Allahbadi (1090 
Curriculum of Islamic institutes in sub continent

\section{$\mathrm{AH} / 1678 \mathrm{CE})$}

- Shafiyah: Ibn Hajib (646 AH/1249 CE)

7) Balaghat

- Mukhtasar Al-Maani: Saad Ad-Din Taftazani (796 AH/1389 CE)

○ Matool: Saad Ad-Din Masood bin Umar Taftazani

8) Kalaam

- Sharh Aqaaid Nasfi: Saad Ad-Din Taftazani

- Sharh Aqaid Jalali: Jalal Ad-Din Diwani (908 AH/1502 $\mathrm{CE})$

- Sharh Mawaqif: Syed Shareef Jurjani (816 AH/1413 CE)

- Risalah Meer Zahid: Meer Muhammad Zahid Harwi (1101 AH/1690 CE)

9) Mantaq

- Qutbi: Qutb Ad-Din Razi

- Salam Al-Uloom: Qadi Muhibullah Bihari

- Meer Qutbi: Meer Syed Shareef Jurjani

- Sughrah: Meer Syed Shareef Jurjani (816 AH/1413 CE)

- Kubra: Meer Syed Shareef Jurjani (816 AH/1413 CE)

- Aisagoji: Atheer Ad-Din Abhari (745 AH/1344 CE)

- Tahdeeb: Saad Ad-Din Taftazani (792 AH/1389 CE)

- Sharh Tahdeeb: Abdullah Yazdi (981 AH/1575 CE)

10) Falsafa/Hikmat 
Curriculum of Islamic institutes in sub continent

○ Sharh Hidayah Al-Hikmah (Mabzi): Meer Hasan Mebzi (1096 AH/1685 CE)

- Sidrah: Sadr Ad-Din Muhammad bin Ibraheem (1051 $\mathrm{AH} / 1640 \mathrm{CE})$

- Shams Baziga: Mullah Mahmood bin Shaikh Muhammad bin Shah Muhammad Farooq Joonpuri (1062 AH/1652 CE)

\section{1) Mathematics}

- Khulasa Al-Hisaab: Biha Ad-Din Aamli (1031 AH/1622 CE)

- Tahrir Aqleedas: Khawaja Naseer Ad-Din Tusi $(672$ $\mathrm{AH} / 1275 \mathrm{CE})$

- Tashreeh Al-Aflaak: Baha Ad-Din Amli (1031 AH/1622 $\mathrm{CE})$

- Risala Qoshanjia: Ala Ad-Din Qawshanji (879 AH/1474 CE)

- Sharh Chagmeeni: Allama Musa Pasharumi (823 $\mathrm{AH} / 1437 \mathrm{CE})$

\section{THE PROCEDURE TO CHOOSE BOOKS IN “DARS-E-NIZAMI:”}

The selection of subjects and the books related were finalized after a great introspection. As stated before the goal that was kept in mind when choosing was the education of the student and how to make him a good citizen of society. To act as a good 
Curriculum of Islamic institutes in sub continent

member of society was the impetus behind these selections. The selections are further expounded in the following points:

NUMBER OF SUBJECTS AND BOOKS:

Eleven subjects had 43 books, through which we see that intellectual books were 20 in number thus half or $47 \%$ of curriculum was of intellectual kind. In linguistics the number of books were 14 i.e. $32 \%$ of curriculum. The transmitted subjects had 9 books which is only $21 \%$ of curriculum. So it can be said that Islamic books were less in number but from these books also only selected pieces were taught.

- CHOICE OF BOOKS:

The creator of "Dars-e-Nizami" had some principles with which he chose the books which are the following:

Easy to More Difficult: It was tried to choose those books which were difficult rather than easier. Therefore so that they have more principles and rules in them.

Shorter to Lengthy: It was tried to choose books which were encompassing and shorter rather than longer so that in few words many things could be explained in a chapter.

Due to these reasons one great seat of learning in Pakistan called Abu Baker Islamic University in subject of Arabic Grammar (Ilm-Nahw) in the first stages of secondary students are taught "Tuhfah As-Siniyah" which is short and encompassing. With whose help the identification of Arabic 
punctuations. And in the last stages of secondary and more difficult and lengthy book called "Qadr An-Nida Wa Bal AsSida" is taught by which a student understands the principles of Arabic Grammar. When in College he is taught "Sharh Ibn Aqeel" where different schools of thoughts in Arabic grammar, disagreements and detailed studies are included. ${ }^{9 \prime}$

THE GOALS FOR CHOOSING THE BOOKS:

Generally the most difficult books were chosen in "Dars-eNizami" in every subject. The reason behind this thinking was that more hard work would be needed to understand these books and thus the cognition was increased likewise, the sight would be deep and the strength would in-crease. What need the difficult books fulfill are also done by shorter books. Thus through research the most concise books were included in the curriculum. A book which is difficult and concise makes the intellect strong and the intense the exercise the more the ability to understanding would increase. So the two goals when designing "Dars-e-Nizami” were:

To increase the ability to study more: When the students graduate after reading such difficult books they would be able to read at a higher level and no book would be difficult for them

${ }^{9}$ Jamia abi bakar al-islamia, sallaybus book, Karachi, 1985, p: $31-32$ 
to read and understand. Also the student after graduating could make this quality extend further so that he could reach a level of completion through hard work.

\section{DEPTH OF SIGHT AND INTELLECT:}

To understand such a curriculum students had to work harder and the cognition is exercised more so. The harder the exercise the deeper understanding and sharper thought is born. This is the reason for the curriculum' philosophical foundation.

\section{CURRICULUM BOOKS WERE CHOSEN WITH FORESIGHT:}

Mullah Nizam Ad-Din Sihalwi when creating "Dars-e-Nizami" had a larger goal. He chose books that were outside of Hanafi school of thought even though he was a Hanafi.

$\mathrm{He}$ also chose books that were not from Sunni scholars. For the Tafsir of Quran the curriculum has (Jalalain whose both authors: Jalal Ad-Din Suuti (911 AH/1505 CE) and Jalal AdDin Mahli (864 AH/1459 CE) and Bedawi's author Nasir AdDin Bedawi (685 AH/1286 CE) and Hadith's only book Mishkat Al-Masabih's author is Wali Ad-Din Iraqi (760 AH death) were all Shafi scholars. In Arabic grammar (Nahw) Sharh Miyah Amil's author Abudul qahir (1081 AH) is also a Shafi scholar. In Nahw's curriculum "Kafiyah" and Sarf's 
curriculum had "Shafiyah", both of these books were authored by Ibn Hajab (646 AH/1249 CE) is a Maliki scholar. Other than Sunnis even Shia scholars were included in the curriculum. In philosophy and intellects the book names Sidra is authored by Sidr Ad-Din Sherazi (1051 AH/1640 CE), the book on Riyadi Khulasatul Hisab and Tashreeh Al-Aflaak was written by Baha Ad-Din Amli (1031 AH/1622 CE), Tahrir Aqlees's author Khawaja Naseer Ad-Din Tusi (672 AH/1275 CE) and Mantaq's book author according to one research is, Qutb Ad-Din Razi is also Shia ${ }^{10}$.

Even though Mullah Nizam Ad-Din chose two books of Hanafi Fiqh in the curriculum namely Hidayah and Sharh Wiqayah. He only selected the worship portion of Sharh Wiqayah and dealings portion of Hidayah for the curriculum.

\section{ERADICATING TASAWWUF FROM THE EDUCATION CURRICULUM:}

Before Dars-e-Nizami Tasawwuf was an integral part of the Islamic curriculum in Islamic institutes.

The current curriculum discarded Tasawwuf from it which was against the Islamic tradition. It should be kept in mind that

\footnotetext{
${ }^{10}$ Ghazi, Dr Mahmood Ahmad, Muslmano ka deeni wa asri nizam taleem, compiled by Dr syed aziz-ur-rehman, al-shariah academy, Gujranwala, 2009, p:48
} 
Mullah Nizam Ad-Din Sihalwi had good relations with Aurangzeb Alamgir and it was the former who gave a place for an institute to the latter to establish an institute. Alamgir didn't have a good view of Tasawwuf and even the works of Mujadid Alf Thani Shaikh Ahmed Sirhandi letters called "Maktoobat Imam Rabani" were banned to be read in the institute. This could be the reason that Mullah Nizam Ad-Din didn't include Tasawwuf in the curriculum. ${ }^{11}$

In $1866 \mathrm{CE}$ Dar-ul-uloom was founded and with slight alterations the curriculum of Mullah Nizam Ad-Din was used. The curriculum had no place for Tazkiyah, Tasawwuf and Sulook and Ihsan in curriculum books. But through the graduates of Dar-ul-uloom Deoband Maulana Taqi Usmani says:

"...All the graduates after graduating went to a Shaikh for reformation. All the famous Ulaama of the institute have taken guidance in reformation from a Shaikh. In the earlier years of Dar-ul-uloom Deoband there was no teacher who was good in books and not good in his personality. Their acts and goals were clear. Their intentions were clean and good. There manners

\footnotetext{
${ }^{11}$ Muhammad akram, sheikh, raud-e-kausar, idara saqafat-eislamia, Lahore, 1988,p:606
} 
impeccable. Their minds were free from this world's trials. They only taught for the pleasure of Allah. It is sad that now graduates from Islamic institutes don't go to a Sheikh to rectify themselves ${ }^{12 \text { ". }}$

\section{THE REASONS FOR THE SUCCESS OF DARS-E-NIZAMI}

The reasons for success of this curriculum are the following:

1- Mughal Emperor Aurangzeb was a religious figure who was righteous and who feared Allah. His relations with Mullah Nizam Ad-Din Sahalwi were the main reason behind the success of the curriculum and such a wide acceptance. Similarly during the Abbasid rule the Fiqh Hanafi was accepted as the Fiqh of the state and even in Andulus Fiqh Malaki was accepted as the Fiqh of the state. This is the reason we see Maliki Fiqh being practiced in Africa wherever the Andulus state had ruled.

2- Also due to circumstantial need of the time the curriculum was widely accepted of Mullah Nizam AdDin Sihalwi. When the British captured the three provinces (Bengal, Bihar and Arisa) of India there was a

\footnotetext{
${ }^{12}$ Usmani, Mufti taqi, Hamara nizam-e-tealeem, maktaba dar-ululoom, Karachi, P:99
} 
dire need of Ulama, Mufti and Qadi to deal with the matters of the Muslims. Since the graduates of "Madrasa Farangi Mahal" were known for being erudite they were accepted and so was the curriculum they were taught in other institutes.

3- After the war of 1857 CE when Dar-ul-uloom Deoband was created in $1866 \mathrm{CE}$ they chose this curriculum over others. Also ever since other institutes were founded they continued to choose this curriculum over others because they had a good example in front of them in terms of results.

4- After the creation of Pakistan scholars created institutes. Since they were taught the same curriculum when they were studying so they chose to keep with the tradition and chose the same curriculum in their institutes.

5- Since this curriculum had no issues with different sects like Deobandis, Barelvis, Shia or Sunni so all sects accepted this curriculum and this made it more popular and religiously accepted.

6- In the religious community there is a lot of respect for elders. Also among scholars there is a preference of old to the new. Since this curriculum was designed by the earlier generation and this is what the teachers of the scholars were taught themselves and taught them they 
chose to keep with the tradition. The reason was that the scholars were historically focused, reverent to the elders and remembering the past.

\section{THE NEW THINKING IN CURRICULUM CREATION:}

In this region of the world the goal of Islamic institutes was to provide to society mosques and institutes (madrasaas). Also to have Imam, Hafiz, Mufti and Khateeb in them so that Muslims have a connection to their worship and there is no break up between them and Islam. In the beginning there were no issues to this approach but with time came more needs to be fulfilled and this need spread into other areas of life. So there was a need of Islamic leadership on issues which such as international issues of importance and according to those needs there was no hesitancy felt in changing the curriculum accordingly. This is so that Islamic institutes should become beneficial to the Muslim nation.

Relating to that there is an incident of Muhammad Qasim Nanatooi. Once he was traveling by sea when he met a German. He needed a translator to converse with him. After that he made a decision to learn English upon his return since he felt the need for it.

Thus it was decided by all schools of thought that with the leaders of federal government that they would include basic 
sciences from the modern education in their curriculum as much as they can. There are some institutes who have already done so.

Another idea was that after secondary the teachings of modern education are impossible with Islamic education. After secondary the phase of mastering and knowing a certain field starts, this is the reason medical colleges don't teach engineering and vice versa. Thus no modern education could be taught after secondary in Islamic institutes.

It could be said on this point that if not deep studies but some important and basics things could be taught by Islamic institutes that are the need of the society. This includes politics and economics in which our society is blindly following the west by borrowing from them even though we have a good model for ourselves.

As there is a need on this point, it can be further elaborated like done in Abu Bakar Islamic University, Karachi in specialization level a compulsory course called "current Islamic World" and the Intellectual invasion (Al Ghazw-ul-Fikri) through which the Muslim nation could be told of the past and the present. This also includes deterioration and ascendency, reasons and results of both could be taught to the Muslim nation. Among this other 
subjects could be taught which mean to prepare us for the intellectual war. ${ }^{13}$

Therefore the modernization done in Islamic institutes could be laid out in the following points

1-The introductory study of present day religions with comparative study to Islam.

2-The introduction to points to know for Muslim nation which include Fiqh and Aqaid issues.

3-The knowledge of modern ideological revolutions.

4-Medicine, Science and Information Technology have a huge impact on society. Under-standing and giving verdicts on issues like Nikah on Skype and Talaq on email etc. Such matters have increased their importance so knowledge of such matters in paramount.

5-To get an understanding and usage of modern communication methods.

6-Sociology and Psychology should be taught and the openness to change through times so that stagnancy does not creep in.

${ }^{13}$ Jamia abi bakar al-islamia, sallaybus book, Karachi, 1985, p: 40-41 
KEEPING THE TRADITIONS IN DIFFERENT SCHOOLS OF THOUGHT

The curriculum in Islamic institutes was created according to Dars-e-Nizami but all different schools of thought took the subjects and used their own books in it.

1) In Barelvi institutes the Tafsir book was Kanz Al-Iman and commentary points on it they used Bedawi and Zamakshari.

2) While Ahl-e-Deoband used Mariful-Quran or Ahkam-ulQuran by Jassas.

3) While Ahl-Hadith used Ibn Kathir and Fath Al-Qadeer. To make a good understanding between different schools of thought there needs to be collaboration in curriculum creation. For this reason a "Curriculum Collaboration Committee" could be created. In current times this committee could be created under "Itihad Tanzeemat Madaris Pakistan".

In future with the government of Pakistan and "Itihad Tanzeemat Madaris Pakistan" working together this would be the right step in the direction. It is important that all schools of thought are represented in this joint curriculum committee. To analyze the current curriculum, make changes and plan a curriculum for the future could be some of its duties. This committee doesn't only need resources but guiding principles which should be set from the beginning. Regarding the joint 
curriculum there are still subjects and topics which are shared by all schools of thought in their curriculum.

For example Sarf, Nahw, Maani, Bayan, Mantaq etc. If "Itihad Tanzeemat Madaris Pakistan" publishes these books under its name it would good for morale and psychological esteem.

In institutes where modern education is imparted and the requirement for admission is secondary level the students have already studied this common curriculum subjects.

To bring different schools of thought together the Curriculum Collaboration Committee could do a lot. To achieve this goal we have to step forward. We should remember that difference of opin-ion will still exist and there is no issue with that. All the scholars from all schools know that.

1- To list all the common parts of the curriculum and joint selection of books as much as possible with the "Itihad Tanzeemat Madaris Pakistan" approval and sponsorship for their publication.

2- Inclusion of books according to today's needs and their inclusion in the curriculum.

3- The preparation and publication of common parts in the curriculum on the platform of "Itihad Tanzeemat Madaris Pakistan."

4- Regarding the disputed matters, preparation of books where different points of view with their proofs presented 
in a good way.

\section{THE FOUNDATION OF ISLAMIC CURRICULUM IN PAKISTAN:}

All schools of thought are under a board (Wifaq) through which they are registered. The power of examinations and degrees is under the hand of Wifaq. Every Wifaq has one curriculum to which all institutes aligned with are tied to. Other than this curriculum each institute can teach any subject to its liking .

After that all Wifaq are divided into three categories. The curriculum is affected by this division due to differences of opinion.

Fiqh Hanafi:

In the Wifaq, the Wifaq Al-Madaris Al-Arabia (Deobandi), Tanzeem Ahl-Sunnat Pakistan (Barelvi) and Rabitah AlMadaris Al-Islamia Pakistan (Jamaat Islami) is according to Hanafi Fiqh. That is why these three have similar curriculums .

Fiqh Jafri: Wifaq Al-Madaris As-Shia's curriculum is according to its own fiqh.

Ahl-Hadith: Since Ahl-Hadith take directly from the Quran and Sunnah that is why they are not restricted to a certain Fiqh. Their curriculum is largely based on narrations. Ilm Kalam and Ilm Mantaq or Falsafa have no portion in the curriculum. 
TIME PERIOD FOR “DARS-E-NIZAMI”

The time period for "Dars-e-Nizami" is for eight years and this division is based on four levels.

1- Al-Ammah level, 2 year (equal to Secondary School Certificate)

2- Al-Khasa level, 2 year (equal to higher school certificate)

3- Al-Aaliaah level, 2 year (Graduation)

4- Al-aamiyah, 2 year (Master in subject)

Each level comprises for two years, the exams of Wifaq has one year gap in between. In this one year the institutes can teach any subject. In some institutes the same subject or taught through different books, White others teach modern subjects.

After the changes in curriculum of Islamic institutes due to current needs

Pakistan was created in 1947 but before its creation there were many institutes already spreading the light of Islam. After independence when many scholars migrated they created more institutes even till today as seeing the need. Today Pakistan has about 18,000 to 20,000 institutes of Islam. The Indian subcontinent had many schools of thought before the creation of Pakistan. Thus creation of institutes according to this division remained after Pakistan. 
To strengthen the system and centralize the institutes according to the schools of thought five Wifaq were created. Today most of the institutes are registered to one of them except for few.

1- Wifaq Al-Madaris Al-Arabia (Deobandi)

2- Tanzeem Al-Madaris Ahl-Sunnat Pakistan (Barelvi)

3- Wifaq Al-Madaris As-Salifiyah

4- Wifaq Al-Madaris As-Shiah (Ahl Tashee)

5- Rabitah Al-Madaris Al-Islamiah (Jamaat Islami) After this division there is joint Committee called "Itihad Tanzeemat Madaris Deeniah" which represents the institutes. Other than that all institutes have increased the number of books in the curriculum. The curriculum for Dar-ul-uloom Karachi is for 17 years. The primary stage is for five years. The middle stage is for three years. The secondary stage also called Ammah is for three years. The intermediate stage also called Khassah is for two years. Graduation stage also called Aliah is for two years. Post-graduation stage also called Alamiah is for two years. The first three stages has curriculum that comes from the government.

Wifaq Al-Madaris As-Shiah's curriculum is for 12 years. The basic division is done on Tafseer, Hadith and Fiqh. While Adab and Nahj Al-Balagah is divided in different years . 
RECOMMENDATIONS :

The steps to be taken in each subject could be described as below:

Ilm Usool: The viewpoints of all the representing scholars of different schools of thought should be included. Within which whose opinion is what is highlighted with their proofs.

Fiqh and Ahkam: A similar book could be compiled on this topic as well. Considering that there are no huge differences in this. Wherever there is a difference of principle it could be solved through dialogue and in a civilized manner. The difference of Hadith sources could be termed as a fundamental difference. Gradually and slowly a complete age of Ahkam could be created. With teaching of Ahkam the philosophy of Ahkam should be included as a subject in the curriculum. In this light creating a joint curriculum doesn't seem too difficult. Philosophy of Ahkam and the study of disputed matters' basic and secondary value would be understood and this would be a source of unifying.

Shared Ahaadith: While working on Fiqh issues in a collaborative selection would be formed but for this goal a separate effort also needs to be made.

Ilm Aqaid:: A book should be produced where shared ideologies and differences both are shown. Like Ilm Usool the disputed matters should be backed up by proofs. 
The historical evolution of Islamic Knowledge: Ilm Hadith, Ilm Usool Fiqh, Ilm Fiqh, Ilm Kalam and Falsafa etc. historical evolution of these subjects should be in the curriculum of Islamic institutes which would be useful. Scholars of different schools of thought could be benefited from this. Studies of this subject should tell the student the historical evolution of education and to ingrain in them that education is not a stagnant thing but is evolutionary in nature and will continue to be so and the scholars of future have to play their role in it.

Seerah Nabwi: A set and joint collaborative book on the biography of the Prophet should be the job of the Curriculum Collaboration Committee. It should be kept in mind that biography of the Prophet and the history of the Prophets are two different topics. The biography has to do with the actual life events.

Principles of Understanding the Quran: "Principles of Understanding the Quran" subjects should be that part of the curriculum of Islamic institutes. However different scholars have adopted different views in this regard. We should not hold our self to a certain school of thought since Quran is the book of the Muslims. To understand it the principles should be known to an Islamic student.

Islamic Conduct: Islam has its own ideology and philosophy of conduct. There are some morals that other religions and codes 
consider not as right but also as necessary. On this topic a joint book should not be difficult to develop. In our view not only trainings in conduct should be a part of it but also the philosophy of conduct should also be included in the curriculum. In this book Muslims rights to each other and in society should be introduced.

Modern Language Studies: Part of the modern languages should be included so that it could help in understanding of texts.

World Religions and Systems: The world's other major religions and ways of life should be known to a Muslim Islamic student. Their fundamental books, key figures, basic beliefs, brief history, sects, their members and their customs/traditions could be some topics which can be added in the curriculum. However a book written by an individual or individuals from the professors of that belief is better and trustworthy with benefits. Within it interfaith dialogue could also be included.

In the above lines it was signaled that some schools of thought don't consider some subjects as important to be worthy of an Islamic education. Our view is that to reject an opinion it is important to study that opinion, which is mandatory. That is why there is no harm in studying. It shroud be kept in mind that the best right to explain an opinion, school, sect or religion is for those who profess it. To achieve this optimal level we could go gradually towards it. 
The Scholar Islamic Academic Research Journal

Vol. 6, No. 1 || January-June 2020 || P. 135-162-

https://doi.org/10.29370/siarj/issue10ar12

Regarding this matter it is clear without saying that the creation and design of curriculum is ac-cording to the level of education, need and ability of students. Our point is taking in the whole of the argument.

\section{(ब)(8)}

BY NC SA This work is licensed under a Creative Commons

Attribution-NonCommercial-ShareAlike 4.0 International (CC BY-NC-SA 4.0) 